\title{
O NÃO-PODER DO PAPA EM GUILHERME DE OCKHAM
}

\author{
Luis Alberto De Boni*
}

SÍNTESE - Os escritos políticos de Ockham giram ao redor da pergunta a respeito do poder do papa. Como esse poder foi concedido por Cristo, deve-se consultar a Sagrada Escritura para saber o que ela diz a respeito. Mas a exegese bíblica cabe aos teólogos e não aos juristas. $\mathrm{Na}$ qualidade de teólogo Ockham afirma que os poderes do papa situam-se na ordem espiritual e mesmo nessa ordem ele não é ilimitado, pois se atém ao que foi concedido expressamente por Cristo e deve respeitar a liberdade dos fiéis.

PALAVRAS-CHAVE - Guilherme de Ockham Exegese bíblica. Plenitude do poder. Poder. Liberdade.
ABSTRACT - The political writings of Ockham circle around the question regarding the power of the pope. As such power was conceded by Christ, one must consult the Holy Bible to know what It tells about such power. However, biblical exegesis belongs to the theologians, not to jurists. As a theologian, Ockham states that the powers of the pope are set in the spiritual order, and even in such an order they are not without limits, for they are conformed to what was expressly conceded by Christ and must respect the liberty of the followers.

KEY WORDS - William of Ockham. Biblical exegesis. Plentitude of power. Power. Liberty.

Procuro mostrar, no presente texto, que o esforço teórico para delimitar o âmbito do poder papal exigiu de Ockham a elaboração de uma teoria, onde surgiram novos conceitos e conceitos antigos tiveram que ser revistos. Ockham não foi propriamente um politólogo, mas um teólogo, casualmente arrastado para a política. Por isso, a leitura de seus textos políticos deve ser feita pelo viés teológico.

A questão do poder é recorrente nos escritos políticos de Guilherme de Ockham. Ela esteve quase sempre ligada à pergunta sobre a plenitudo potestatis, isto é, sobre a pretensão de poder ilimitado por parte do papa e, por conseqüência, aos limites entre o poder religioso e o poder civil, poderes esses que, personificados em seu tempo nas figuras do sumo pontífice e do imperador, haviam entrado em rota de colisão. Três obras ockhamianas enunciam já no título que a plenitude do poder conferido ao papa constitui o tema central delas: Octo quaestiones de potes-

Pontifícia Universidade Católica do Rio Grande do Sul / Porto Alegre.

\begin{tabular}{|l|l|l|l|l|l|}
\hline VERITAS & Porto Alegre & v. 51 & n. 3 & Setembro 2006 & p. 113-128 \\
\hline
\end{tabular}


tate papae, Breviloquium de principatu tyrannico e De imperatorum et pontificum potestate.

\section{Situando o problema}

Durante o século XIII e início do século XIV, sob influência da cúria romana, desenvolveu-se na Igreja uma teoria hierocrática, afirmando que o papa, enquanto vigário de Cristo, estava revestido de poderes extraordinários e, mais do que isso, que era através dele que se constituía todo o poder neste mundo. Aplicando à realidade política a metafísica neoplatônica da unidade e a da subordinação do imperfeito ao perfeito, deduzia-se das emanações sucessivas, a partir do Uno, também a procedência do poder que, tendo sua origem em Deus, descia, primeiramente, ao sumo pontífice, e desse se estendia para as demais autoridades, todas inferiores a ele. Nessa teoria, o poder temporal não se tornava supérfluo, mas afirmava-se que ele era posto na existência através do poder religioso e agia subordinado ao sumo pontífice que, em casos extraordinários, poderia nele intervir. Documentos de Inocêncio III, Gregório IX, Inocêncio IV e Bonifácio VIII, juristas renomados, mostram como se elaborou a teoria da plenitudo potestatis entre os papas romanos, podendo-se considerar a bula Unam sanctam, de Bonifácio VIII, como o resumo de todas as pretensões papais. ${ }^{2}$

Entre os defensores dessa forma de absolutismo eclesiástico, encontravam-se juristas e teólogos. Entre esses citem-se, devido à relevância das obras: Tiago de Viterbo, a quem coube o mérito de haver, por primeiro, escrito um tratado sistemático sobre a Igreja; ${ }^{3}$ Egídio Romano, cujo De ecclesiastica potestate ${ }^{4}$ constituiu a mais brilhante teoria do poder absoluto dos papas e um dos textos políticos de maior relevância da Idade Média; e o franciscano Álvaro Pais, com o De statu et

Guilherme de Ockham. Octo quaestiones de potestate papae. (ed. H. S. Offler) 2. ed. Manchester: MUP, 1974, Opera política I, p.1-217 (trad. portuguesa de J. A. de C. R. de Souza. Oito questões sobre o poder do papa. Porto Alegre/Bragança Paulista: Edipucrs/EUSF, 2002); Breviloquium de principatu tyrannico (ed. H. S. Offler) London: British Academy, 1997, Opera politica IV, p. 81-260 (trad. portuguesa de L. A. De Boni. Brevilóquio sobre o principado tirânico. Petrópolis: Vozes, 1988); De imperatorum et pontificum potestate (ed. H. S. Offler) London: British Academy, 1997, Opera politica IV, p. 263-355 (trad. portuguesa de J. A. de C. R. de Souza. Sobre o poder dos imperadores e dos papas. In: Guilherme de Ockham - Escritos políticos. Porto Alegre/Bragança Paulista: EdipuCrs/EUSF, 1999, p. 165-254). No presente trabalho atemo-nos principalmente às duas últimas obras que constituem, de certo modo, o compêndio do que o autor escrevera a respeito, durante os anos de exílio em Munique. As indicações de página referem-se ao texto latino da edição crítica, seguindo-se, entre colchetes, a página da tradução para o português.

2 Sobre o debate a respeito do poder papal na Idade Média, cf., dentro da imensa bibliografia: J. Miethke. Die päpstliche Amtskompetenz im Widerstreit der politischen Theorie von Thomas von Aquin bis Wilhelm von Ockham. Tübingen: Mohr-Siebeck, 2000 (tradução italiana: Ai confini del potere: Il dibattito sulla potestas papale da Tommaso a Guglielmo d'Ockham. Padova: Editrici Francescane, 2005).

3 Cf. H.-X. Arquillière. Le plus ancien traité de l'Église - Jacques de Viterbe: De regimine Christiano (1301-1302). Paris: Beauchesne, 1926.

4 Aegidius Romanus. De ecclesiastica potestate (ed. R. Scholz) Aalen, 2. ed. 1961 (trad. portuguesa de C. P. Goldman e L. A. De Boni. Egídio Romano - Sobre o poder eclesiástico. Petrópolis: Vozes, 1989). 
planctu ecclesiae ${ }^{5}$ que representou a última grande tentativa de defesa das ambições desmedidas do bispo de Roma.

Em 1324, portanto, poucos anos antes de Ockham se envolver em questões políticas, as pretensões da cúria romana defrontaram-se com um desconcertante e arrasador ataque provindo de Marsílio de Pádua. O italiano parecia ser um "averroísta" - para usarmos um questionável clichê - isto é, um pensador que reduzia a filosofia aos limites da razão, sem admitir que argumentos teológicos pudessem ser alegados no discurso filosófico ${ }^{6}$. Com esse pressuposto, elaborou, no Defensor pacis, ${ }^{7}$ uma teoria política de aparência puramente aristotélica. Tal como o filósofo grego, ele concebeu a sociedade humana como fechada em si mesma e para si mesma suficiente, e capaz, por suas próprias forças, de chegar à felicidade. Mas o aristotelismo marsiliano era metodologicamente bem outro que aquele do pensador grego, pois transformava a política, de ciência da probabilidade e do possível, em uma ciência apodítica.

A sociedade, pensava Marsílio, é colocada na existência pela decisão de seus próprios membros, os quais constituem o poder legislativo supremo. Ela é a realização plena do homem, o que significava voltar a dizer, com os gregos, que a moral individual se completa na política. Essa concepção, fiel a Aristóteles, afastava o autor da reviravolta efetuada por Tomás de Aquino, para quem a política se subordinava à ética; e, graças a tal concepção, Marsílio propunha redefinir o espaço do poder espiritual dentro da sociedade política. Os membros da Igreja se transformavam, então, tal como em Aristóteles, em uma das seis classes sociais em que se dividiam os cidadãos, e a religião passava a ser uma das partes do todo maior do Estado, ficando sob a vigilância e servindo aos interesses deste. O papa, despojado de autoridade política, era igualado, em nível religioso, aos demais bispos, todos sujeitos ao imperador, a quem competia convocar e presidir o concílio. Assim, Marsílio retirava do papa a plenitudo potestatis, transferindo-a, porém, para o imperador. Era inegável a modernidade da proposta que, inclusive, abria o caminho para o absolutismo dos séculos seguintes. ${ }^{8}$

5 Álvaro Pais. De statu et planctu ecclesiae / Estado e pranto da Igreja. Pref. Francisco da Gama Caeiro; introd. João Morais Barbosa; estabelecimento do texto e trad. Miguel Pinto de Meneses. Lisboa: Junta Nacional de Investigação Científica e Tecnológica, 6 vols., 1988.

6 Sem dúvida, a qualificação de 'averroísta', atribuída a Marsílio, precisa ser encarada com muitas reservas. Aliás, o próprio termo 'averroísta' foi muito criticado nos últimos decênios. G. Piaia, com quem concordamos plenamente, mostrou com muita competência que o averroísmo marsiliano é algo que não se sustenta e que possui raízes ideológicas na historiografia do século XX (cf. G. Piaia. "'Averroismo politico' - Anatomia di un mito storiografico". In: Id. Marsilio e dintorni. Padova: Antenore, 1999, p. 79-103).

Marsilius von Padua. Defensor pacis (R. Scholz, ed.). Hannover: MGH, 1932 (trad. portuguesa J. A. de C. R. de Souza. Marsílio de Pádua - O defensor da Paz. Petrópolis: Vozes, 1997). Sobre a crítica à plenitude do poder nesse autor, cf. S. R. Strefling. Igreja e poder - Plenitude do poder e soberania popular em Marsílio de Pádua. Porto Alegre: Edipucrs, 2002.

8 Diga-se, de passagem, que os contemporâneos e os que se sucederam nos primeiros séculos, parecem não haver percebido claramente o alcance da obra marsiliana (Ockham deve ter sido exceção), a qual foi interpretada de diversos modos e com diversas finalidades (cf. G. Piaia. "A fortuna do 'Defensor pacis'”, in: J. A. de C. R. de Souza, Marsílio de Pádua... Introdução, p. 41-59). 
Ockham era por demais filósofo e por demais teólogo para aceitar pura e simplesmente a argumentação do italiano, seu colega de exílio, de quem discordou em pontos fundamentais ${ }^{9}$. Havia, porém, outras duas fontes das quais se poderia valer em sua crítica. Uma delas estava dentro de sua própria Ordem, no movimento dos 'espirituais', cuja defesa da pobreza anunciava, para o futuro, uma Igreja também pobre e não envolvida nos negócios do mundo. ${ }^{10}$

A outra fonte, porém, era-lhe muito mais importante: o De regia potestate et papali, do dominicano João Quidort. ${ }^{11} \mathrm{O}$ texto surgiu entre 1302 e 1303, durante o debate entre Bonifácio VIII e Filipe IV, o Belo. Quidort distinguia entre a origem humana do poder civil, fundado na tendência natural do homem para a polis, e a origem divina do poder eclesiástico, instituído por Cristo. O poder civil, dizia ele, é por natureza limitado, pois só chega até onde alcança a força do braço armado; já o poder eclesiástico, por natureza e por instituição divina, não possui limites, pois a palavra, que o caracteriza, pode alcançar todos os recantos da terra. O rei preside ao do poder civil; na Igreja, Cristo é a autoridade primeira, da qual o papa é um simples ministro, um instrumento.

A maior dignidade do poder espiritual, em comparação com o temporal, não significa que ele seja a origem deste ou que este lhe esteja submetido diretamente. Há uma independência de domínios entre os dois poderes, e o papa sequer possui a plenitude do poder dentro da Igreja. Consultando a Escritura, que é a fonte da doutrina cristã, constata-se que Cristo, enquanto homem, não possuía tal plenitudo potestatis, que o constituísse como senhor de reinos e proprietário de todos os bens. E mesmo aqueles poderes, que ele possuiu como salvador, não foram todos conferidos a Pedro e aos sucessores de Pedro. Seis foram os poderes que ele legou à sua Igreja: (1) o poder de consagração da eucaristia; (2) o poder de administrar os sacramentos; (3) o poder ou ofício do apostolado; (4) o poder de correção do pecador no foro externo pela repreensão e até mesmo pela excomunhão, mas sem força coercitiva; (5) o poder de distribuir os ministros quanto à jurisdição eclesiástica; (6) o poder, ou direito, de receber o necessário para a vida.

Quidort não negava o primado do papa na Igreja, nem colocava a Igreja a serviço do poder civil, mas, progredindo pelo caminho anteriormente trilhado por Tomás de Aquino, abria espaço para duas esferas independentes e nãoexcludentes de poder, deixando bem especificado o alcance de cada um deles. A partir desses pressupostos, estava sendo desmontada a teoria da plenitudo potes-

9 Infelizmente, pelo que conhecemos, não existe até hoje um estudo de fôlego a respeito das divergências entre Ockham e Marsílio.

10 Sobre os espirituais, cf. M. Lambert. Povertà francescana. Milano, 1995 (ed. inglesa, 1961); AA. VV. Chi erano gli spirituali. Assisi (Atti del Convegno Studi Francescani), 1976; R. Lambertini e A. Tabarroni. Dopo Francesco: L'eredità difficile. Torino, 1989; D. Burr. Olivi e la povertà francescana. Milano, 1992 (ed. americana, 1989); N. Falbel. Os espirituais franciscanos. São Paulo: EDUSP, 1995; L. A. De Boni. "O debate sobre a pobreza como problema político nos séculos XIII e XIV", in: Id. De Abelardo a Lutero. Porto Alegre:Edipucrs, 2003, p. 215-254.

11 Johannes Quidort von Paris. Über königliche und päpstliche Gewalt - De regia poteste et papali. Stuttgart, 1969 (trad. portuguesa L. A. De Boni. Sobre o poder régio e papal. Petrópolis: Vozes, 1989). 
tatis, não através de uma crítica externa, de caráter meramente político, como faria duas décadas mais tarde Marsílio de Pádua, mas através de uma crítica intraeclesial, de caráter teológico.

\section{Discutir sobre o poder do papa}

No decorrer do século XIV, em defesa da plenitudo potestatis do papa, desenvolvera-se, por parte da cúria romana, o argumento de que não se podia disputar a respeito do poder do papa. O caráter autocrático dessa tese baseava-se em princípios jurídicos, provenientes do direito romano e assumidos também pelo direito canônico, segundo os quais, "a ninguém é lícito disputar a respeito do juízo do príncipe". ${ }^{12}$ Essa doutrina apoiava-se em outra, proveniente dos séculos IV e V - e que até hoje faz parte do direito canônico -, segundo a qual a Sé primeira, isto é, o bispo de Roma, não pode ser levado a juízo por ninguém. Sendo o papa interpelado, sua palavra faz fé, independentemente de qualquer prova. Assim sendo, também faz fé sua palavra, quando o papa diz quais são os limites do seu poder e, tendo ele falado, não cabe mais discutir a respeito.

Ockham concedia a seus oponentes que podia haver um modo condenável de tratar do problema. Contudo, observava ele: "Deve ser tido como louvável disputar em vista do exercício e da doutrina, para que se convençam os que erram a respeito, por suprimi-la, diminuí-la ou ampliá-la, mais do que convém, e para levar ao conhecimento do público o que dela se desconhece". ${ }^{13}$ E acrescentava um texto de Agostinho, dizendo que onde com mais perigo se erra é no tratado a respeito da Trindade e, no entanto, os grandes doutores da Igreja escreveram sobre a Trindade, pois só assim foi possível saber melhor a respeito e confutar os hereges. Aliás, quanto mais elevado o assunto, mais perigoso pode ser o erro a respeito e, por isso, mais se deve pesquisar sobre ele. E o papa é o primeiro que tem obrigação de conhecer quais são os limites de seu poder, pois, segundo o direito, alguém é tido como culpado, quando ignora aquilo que se refere a seu ofício.

Admitindo-se esse arrazoado, surgia, então, a pergunta crucial: a quem competia precipuamente perquirir a respeito do poder do papa. A resposta exigia que se soubesse por qual direito o papa estava constituído como autoridade. Ora, observava ele, é evidente que nada existe no direito natural que se refira a tais poderes. Portanto, eles devem ser procurados no direito positivo divino ou humano. O direito positivo divino se encontra nas Escrituras; o humano, nas leis que os homens fizeram, tanto em âmbito civil, como eclesiástico. Constata-se, então, que o papa possui alguns poderes por direito divino, outros, por direito humano, devido à concessão da parte de imperadores e príncipes. Não pode, pois, o papa fundamentar no direito canônico o poder de ordem, de pregação, de receber da co-

12 Brev. I, c. 1, p. 99 [31]. Este argumento, ao que consta, teria sido elaborado por Guilherme Durando para justificar o poder papal de conceder dispensa (cf. ibid., nota do texto latino).

13 "Disputare autem de potestate papae propter exercitium et doctrinam, ut convincantur circa ipsa errantes, eam videlicet auferendo vel minuendo aut plus quam expediat ampliando, et ut quae de ipsa sunt ignota ad notitiam publicam deducantur [...] laudabile est censendum" (ibid.). 
munidade o sustento, pois esses poderes foram conferidos por Cristo, por direito divino, portanto, e não por legislação humana, e o direito canônico também é legislação humana, tal como o é o direito imperial. E, havendo disputa entre o papa e o imperador quanto ao poder que cabe ao papa por direito divino, não pode o papa arrolar em seu favor o direito canônico, nem o imperador a legislação imperial, pois assim fazendo estariam legislando em seu próprio interesse, principalmente se se considerar que eles poderiam fazer novas leis e, desse modo, legislar e agir como juiz em causa própria.

Feitas essas observações preliminares, podia ele, então, formular a resposta: "Que poder, quanto, em que casos e sobre quem o papa possui, por direito divino e concedido só por Cristo, compete principalmente aos teólogos investigar, não a outros, a não ser na medida em que são levados a tomar algo da teologia". ${ }^{14}$

A frase revelava não só a autoconsciência de Ockham e dos teólogos medievais, mas também as mudanças profundas que estavam acontecendo na divisão de poder dentro da Igreja. Para ser devidamente compreendida, ela precisa ser situada historicamente. O cristianismo não surgiu como entidade com um código de crenças e normas jurídicas, mas como um grupo de pessoas que acreditavam em Cristo e que, no passar do tempo, foram explicitando melhor o conteúdo da fé e encontrando formas de administração da comunidade. De início, os problemas maiores eram resolvidos em reuniões dos apóstolos e anciãos. No final do primeiro século, já estava completo o cânon dos livros tidos como inspirados, que se tornaram, para sempre, a fonte primeira e fundante da vida cristã e também já estava organizado um modelo de administração eclesiástica, que fazia da Igreja uma federação de dioceses. No século IV, consolidaram-se três tipos de autoridade teológica (e disciplinar), iluminadas todas elas pela palavra divina contida nas Sagradas Escrituras: (1) os sínodos, especialmente os concílios da ecumene, (2) os chamados "Padres da Igreja", e (3) o bispo de Roma. No século XIII, com o surgir das universidades, apareceu uma nova figura: o professor de teologia, que se dedicava ex-professo ao estudo e ao ensino da página sagrada. Como elementochave no projeto pontifício de formar quadros para a propagação da fé e o combate aos hereges, sua determinatio - a resposta que somente ele podia dar a uma questão teológica - adquiriu valor doutrinal, e o conjunto dos mestres passou a ser consultado a respeito dos mais importantes problemas referentes à fé e à vida cristã. Instaurou-se, pois, no coração da Igreja um modelo de autoridade, cuja função específica era recorrer aos argumentos da razão para iluminar as afirmações da fé. Foram eles, os professores, que elaboraram a lista de erros atribuídos aos "averroístas", em 1277. O concílio de Basiléia, no século XV, seria impensável sem eles. E, no século seguinte, Lutero ainda sentiu o peso das condenações dos teólogos parisienses.

14 "Ouam ergo et quantam et in quibus casibus et super quos papa habeat potestatem ex iure divino et a solo Christo, inquirere ad theologos principaliter spectat, non autem ad alios, nisi inquantum ad aliqua ex theologia mendicare noscuntur" (ibid .c. 7, p. 105 [37]). 
Este foi o mundo de Ockham. O modo como ele fez teologia não deixava de ter semelhança com o projeto de Severino Boécio, no VI século. Expliquemos: a posição da filosofia ante a teologia fora colocada por Agostinho como uma relação de dependência e de propedêutica daquela ante esta. Somente o conhecimento das coisas divinas era, para ele, sabedoria; o conhecimento das coisas humanas permanecia no nível da ciência e voltava-se à sabedoria, como para seu télos. Mas, para além da sabedoria da tradição neoplatônica, dizia ele, encontrava-se a sabedoria da revelação, e esta sabedoria era Cristo. Agostinho se esforçava, portanto, em integrar a sabedoria pagã na doutrina sobre o Deus do cristianismo e em demonstrar a superação da sabedoria proveniente da filosofia pela sabedoria da fé. Já o problema fundamental para Boécio, nessa questão, era bem outro: tratava-se, acima de tudo, de um debate interno dentro da religião cristã, para o qual só era possível o apelo à razão, visto que, apesar das definições conciliares, não se haviam amainado as disputas pela reta compreensão do dogma. Nessa situação, pensava ele, ficavam bloqueados os argumentos de autoridade, fosse ela da Bíblia, da tradição ou dos concílios, porque as divergentes leituras dos mesmos serviam para reforçar posições antagônicas. "Por isso, para a solução dos problemas de compreensão, resta-lhe somente o recurso à força cognitiva da razão e à capacidade dessa de determinar conceitos e criar regras de argumentação". ${ }^{15}$ Os cinco pequenos 'Tratados teológicos' que escreveu, bem como a Consolação da Filosofia, são exemplo desse novo modelo de trabalho, onde a tradução correta, a gramática, a lógica e a metafísica são colocadas na linha de frente, como as únicas armas aceitas no debate.

Transposta para outro contexto histórico, a posição de Boécio parecia reviver no projeto ockhamiano. Também o debate, no qual o Venerabilis inceptor estava envolvido, chegara a um impasse, na medida em que ambas as partes, entrincheiradas em seus próprios argumentos, pareciam não encontrar um caminho comum a ambas, capaz de possibilitar o debate que levasse a uma conclusão ao menos logicamente aceitável ou irrecusável pelos dois partidos. Os mesmos textos bíblicos, lidos à luz do direito romano ou do direito canônico, conduziam à justificação das aspirações do imperador ou do papa, respectivamente. A proposta ockhamiana mudava totalmente o enfoque. O ponto de partida era o mesmo: o texto bíblico, aceito por ambas as partes como palavra divina, mas chave de leitura era a exegese do texto, que ficava confiada à autoridade dos teólogos, não à dos juristas e dos canonistas.

Para tanto, Ockham percorreu um longo caminho, que exigiu dele a modificação de alguns conceitos fundamentais, como o próprio conceito de Igreja. Assim, por exemplo, a explicação da relação entre fé e razão manteve-se inalterada no percurso de todas suas obras; o mesmo, porém, não aconteceu com o conceito de 'Igreja': em seus primeiros escritos, esta era tomada muitas vezes como sinônimo

${ }_{15}$ M.Lutz-Bachmann. "Metaphysik und Theologie. Epistemologische Probleme in den 'Opuscula sacra' des A. M. S. Boethius", in: Id. et al. Metaphysics in the Twelfth Century. Turnhoult: Brepols, 2004, p. 7. 
de Igreja romana, na qual se encontraria a autoridade maior em questões de fé e, então, fidelidade à Igreja significava aceitação das decisões da Igreja romana. Os textos acadêmicos da Leitura ao II livro das Sentenças e do De sacramento altaris exemplificam bem essa posição. ${ }^{16}$

As peripécias, que se sucederam, mostraram-lhe, porém, que a cúria papal sofria das mesmas deficiências que as outras instâncias e que algumas manifestações do sumo pontífice não se sustentavam quando racionalmente questionadas. Isso o levou a ampliar enormemente o campo da razão em questões de fé. Como professor de teologia, sentiu-se, então, investido de privilegiada autoridade para discutir quais os poderes concedidos por Cristo a Pedro e, depois, aos sucessores deste. Sua investigação pressupunha, contra Marsílio, a existência de uma autoridade divinamente instituída na Igreja e, contra os curialistas, o controle da autoridade por várias instâncias, nenhuma das quais revestida por Deus da infalibilidade. Esta "não pertence de modo próprio a ninguém, nem a uma instituição nem a um indivíduo. Deus, na verdade, não prometeu a infalibilidade a um homem individual, como o papa, nem mesmo a uma coisa abstrata, como é a autoridade papal, nem a um colégio restrito, como o concílio geral e, enfim, nem mesmo a uma pura ficção, como é a idéia de Igreja universal. Deus, prometendo a infalibilidade, garantiu somente que a verdade não desaparecerá no seio da comunidade cristã. Se o papa erra, outras pessoas ficarão fiéis à verdade. Mas nós não podemos saber [de antemão] quem serão". ${ }^{17}$

A verdade da fé se convertia, então, de um dado fixo, em uma longa procura, pois a palavra da revelação não possui tal grau de evidência que possa dispensar o esforço hermenêutico da razão - pelo contrário, exige-o. É trabalho imprescindível do teólogo, e primariamente só dele, de modo lógico e com autocrítica, valer-se de sua bagagem de conhecimentos para levar à compreensão correta do texto sagrado. Nesse empreendimento, de cunho acadêmico, a razão se confronta com a razão, o argumento com o argumento. Não há espaço, então, para condenações baseadas simplesmente na decisão da autoridade - há espaço apenas para o reconhecimento, ante os argumentos da razão, de que uma posição é melhor do que outra, ou de que uma está certa e outra está errada. E quando o debate se vale de argumentos racionais, estreita-se muito o campo das certezas absolutas e ampliase o das probabilidades.

Em seus derradeiros escritos, Ockham abandonou o procedimento anterior de apresentar opiniões divergentes e analisá-las em sua consistência, sem tomar partido de modo manifesto. Embora insistindo sempre que não era dono da verdade, ele passou a opinar e a afirmar, a tomar claramente posição. A respeito, dizia ele no prólogo do Brevilóquio:

${ }_{16}$ Cf. a respeito J. Miethke. Ockhams Weg zur Sozialphilosophie, Berlin: De Gruyter, 1969, p. 264-299. Miethke mostra como Ockham manteve sempre a mesma compreensão do que significa o trabalho teológico e de quais são as relações entre fides infusa e fides acquisita. O mesmo, porém, não aconteceu com sua compreensão de 'Igreja' que, de ínício, era tomada como sinônimo de 'igreja romana' e mais tarde foi tomada como 'comunidade de todos os fiéis'.

7 A. Ghisalberti. Guilherme de Ockham. (trad. de L. A. De Boni). Porto Alegre: Edipucrs, 1997, p. 299. 
Nesta obra [...] afirmarei abertamente algumas coisas e, noutras, sem afirmar temerariamente, opinarei. Protesto, porém, abertamente que, de forma consciente, não direi absolutamente nada contra a fé que nos foi legada por Cristo e pelos apóstolos, e se, por ignorância, disser algo contra ela, disponho-me a aceitar a correção de quem quer que seja que me possa manifestar a verdade. Não obstante isso, no tempo e no lugar oportuno, com prudente solicitude, investigando por mim mesmo ou inquirindo de outros, haverei de procurar a verdade, a qual, se a ignorar, não haverei de me envergonhar em confessá-la publica e abertamente, onde julgar conveniente. Assim, pois, haverei de apresentar com temor o que parecer a mim ser conforme com a verdade, para que possa ser corrigido, se for falso, pelo juízo de alguém mais sábio. As coisas, porém, que pela Sagrada Escritura e por razão evidente ou por outro modo qualquer, são certas, não submeto à correção de ninguém, pois elas devem ser simplesmente aprovadas e de modo algum corrigidas. ${ }^{18}$

De forma semelhante, ele se expressava em Sobre o poder dos imperadores e dos papas:

Peço e imploro a quem venha a ler esta obra, se achar que eu errei em alguma coisa, faça o favor de me mostrar isso com argumentos ou mediante os textos de autoridades, os quais sou obrigado a acatar. Então, se não tiver condições de responder com argumentos consistentes, confessarei ter errado. De fato, de modo algum me envergonharei, se vier a ser derrotado pela verdade, mas não pela força da multidão. Aliás, considerarei esse fato como algo de muito útil para mim. Entretanto, todos seguramente saibam que, nos assuntos de fé e de ciência, antes me convencerá um só argumento evidente ou uma autoridade da Sagrada Escritura interpretada corretamente do que uma assertiva aceita por todo o conjunto dos mortais. ${ }^{19}$

Ora, afirmar que é fiel à fé católica, à qual de modo algum quer contradizer, é algo comum aos medievais; mas dizer que a ortodoxia da fé passa, de algum modo, pelo crivo da razão, não é mais Idade Média; é ir para além de Lutero e aproximar-se dos iluministas e de Kant. Em assim sendo, também em questões de fé o Venerabilis Inceptor tem laivos de modernidade.

${ }_{18}$ "[...] in hoc opere [...] in aliqua asserendo constanter, aliqua absque assertione temeraria opinante [...] procedam et protestor aperte quod contra fidem nobis a Christo et Apostolis traditam scienter nichil omnino dicam, et si aliquid contra ipsam dixero ignoranter, a quocumque, qui michi manifestare potuerit veritatem, corrigi sum paratus. Et nichilominus investigando per me ipsum et quaerendo ab aliis loco et tempore opportunis cauta sollicitudine veritatem inquiram; quam si cognovero, non pudebit me ubi expedire videro patenter et publice confiteri. Sic enim quod pro nunc michi videtur consonum veritati aperiam cum timore, ut velim, si falsum est, sapientioris iudicio reprobari. Quae autem per scripturas sacras vel per rationem evidentem aut quocumque modo sunt certa, nullius correctioni subicio: quia illa approbanda sunt et nullatenus corrigenda" (Brev. Prologus, p. 98 [28]).

19 "Unde rogo et obsecro ut quicumque legerit conscribenda, si me in aliquo errare putaverit, hoc mihi per rationem vel auctoritatem quam recipere teneor, in scriptis dignetur ostendere; et ego, si non valuero rationabiliter respondere, me errasse fatebor. A veritate enim, non a multitudine vinci nullatenus erubescam, sed mihi utilissime aestimabo. Verumptamen, hoc certum habeant universi quod in hiis, quae fidei sunt et scientiae, plus me movebit una ratio evidens vel una auctoritas scripturae sacrae sane intellecta, quam assertio totius universitatis mortalium" (De imp. et pont. potestate, Prol., p. 281 [172]). 


\section{Os poderes do papa}

No ambiente dos séculos XIII e XIV, a pergunta sobre os poderes do papa exigia inicialmente o esclarecimento do que se entendia por plenitudo potestatis.

Por plenitude do poder, afirmava Ockham, os curialistas entendiam que Cristo concedeu a Pedro e seus sucessores "tal poder, nos âmbitos secular e espiritual, de modo que, de direito, pudesse[m] regularmente fazer tudo aquilo que não se opõe nem à lei divina, nem à lei natural" ${ }^{20}$ Para eles, isso possuía um significado positivo, porque estava a indicar que o papa não somente era a autoridade maior existente sobre a terra, mas que era também aquele em quem residia toda a autoridade, podendo, portanto, fazer, por si, tudo aquilo que as demais autoridades podiam fazer.

Para Ockham, pelo contrário, tal tipo de poder e de exercício do poder era considerado como algo de nível inferior, visto que a autoridade é tanto mais perfeita quanto mais livres são as pessoas sobre as quais é exercida e quanto mais se volta para o bem daqueles sobre os quais impera. A nobreza e a dignidade de um governo se medem pela dignidade que nele se reserva aos súditos, não pela amplidão dos poderes do mandatário; não é por poder matar os animais, ou ordenar trabalho aos escravos, que se aquilata a nobreza de um principado, mas pelo grau de liberdade de que gozam os regidos. ${ }^{21}$ Ora, uma autoridade que pode fazer tudo o que não contradiz o direito natural e a lei divina é autoridade que se exerce sobre escravos, não sobre livres. Se o papa possuísse tal autoridade, então, "todos os cristãos, tanto os imperadores como os reis e seus súditos, seriam escravos dele, no mais estrito sentido do termo, porque nunca houve nem haverá alguém que, de direito, tenha maior poder sobre qualquer homem do que aquele que sobre ele pode tudo o que não repugna ao direito natural e ao divino". ${ }^{22}$ Mas, dizia Ockham, isso não se coaduna com a dignidade do papa, que possui o mais perfeito dos principados, porque não possui escravos. Por isso mesmo, não se lhe pode atribuir tal plenitude do poder.

Em segundo lugar, deve-se ter presente, como vimos, que a função primordial do teólogo, segundo Ockham, é praticar a exegese do texto da Escritura, valendose, para tanto, de meios racionais. Não pertenciam, portanto, ao âmbito específico de estudos de Ockham as questões que diziam respeito a propriedades, posses, jurisdições e direitos civis do papa ou da Igreja, pois nada disso constava na Escritura. Para saber sobre esses problemas, cabia consultar a História e a documentação que se conservava a respeito, e ali se constatava que os bens materiais e os direitos sobre eles, que o papa e a Igreja possuíam, eram resultantes de doações,

${ }^{20}$ "[...] talem in temporalibus et spiritualibus plenitudinem potestatis, ut omnia de iure possit regulariter, quae neque legi divinae neque legi naturae repugnant [...] assignavit" (Ibid.,c. 1, p. 283 [173]).

${ }^{21}$ De imp. et pont, c. VII, p. 294 [186].

22 "Omnes enim Christiani, tam imperatores et reges quam quicumque alii ipsis subiecti, essent servi papae secundum strictissimam acceptionem nominis 'servi'; quia numquam fuit nec erit de iure aliquis, qui maiorem habuerit super quemcumque hominem potestatem quam ut posuit in eum omnia quae nec iuri naturali nec iuri divino repugnant" (Brev. II, c. 3, p. 115 [49]). 
concessões, privilégios e cartas, provenientes de imperadores, reis, príncipes e fiéis devotos. ${ }^{23}$ Portanto, duas espécies de poder se refletiam na Igreja: de um lado, o poder que Cristo possuía, enquanto homem, que era poder espiritual, em vista da salvação - e algo deste poder foi concedido por Cristo ao Papa e à Igreja -; de outro lado, havia o poder instituído pelos homens para bem viverem neste mundo, o poder sobre as coisas terrenas, sobre os bens materiais, e este poder o papa não recebeu de Cristo, pois o próprio Cristo, enquanto homem, não o possuía, mas dos imperadores, reis, príncipes e senhores.

A fim de refutar as teses dos curialistas, o teólogo Ockham precisava, portanto, fazer a exegese de diversos textos bíblicos, principalmente o de Mateus 16, 16, onde está dito: "Tu és Pedro e sobre esta pedra edificarei a minha Igreja. [...] Tudo o que ligares sobre a terra será ligado também nos céus [...]". Este era o caminho usado também pelos curialistas para saber quais poderes Cristo concedeu a Pedro e a seus sucessores.

Em primeiro lugar, segundo ele, ficava claro, pela Sagrada Escritura - e lá estavam os Padres da Igreja a apoiá-lo - que Cristo, enquanto homem, não se julgou senhor de impérios e de reinos; que aceitou a autoridade de César, a quem pagou imposto; e que não transformou seu principal apóstolo em príncipe, em instituidor de principados ou em nomeador ou destituidor de reis e imperadores. Também era evidente que Cristo não instituiu reinos ou os legitimou, nem delegou a instituição deles ao papa, para que pudessem ser considerados legítimos. Eles existiram, e eram legítimos, antes que a Igreja existisse e, prosseguia Ockham, valendo-se de Agostinho, ${ }^{24}$ os reinos deviam ser computados entre os bens menores que a bondade divina concedeu aos homens, depois do pecado, para que pudessem conviver pacificamente entre si. $^{25}$

Além disso, o papa não possuía plenitude do poder sobre os bens temporais da Igreja, dos quais ele era apenas administrador. Os bens que a Igreja possui existem para socorrer os necessitados e permitir uma melhor administração eclesiástica. Não pode o papa doá-los a seu talante. ${ }^{26}$ Um dos bens da Igreja, que o papa administrava, eram as terras que constituíam o que depois foi chamado de 'Estados Pontifícios'. Se sobre elas ele não possuía a plenitude do poder, mas era obrigado a bem administrá-las no interesse da Igreja; então, por maior razão, tam-

${ }^{23}$ "Talia enim [res, possessiones, iurisdictiones, libertates et iura] non per scripturas sacras, cum de huiusmodi in ipsis nulla penitus mentio habetur, sed per iura imperatorum, quae de talibus copiose loquuntur, et per instrumenta, privilegia atque cartas imperatorum, regum, principum et aliorum, qui Romanam ecclesiam ditaverunt et libertatibus donaverunt, sciri possunt" (Brev. I, c. 10, p. 109 [40]).

24 Cf. Agostinho. De civitate Dei, l. XIX, c. XIII; n. 2; PL 41, 641s (trad. portuguesa de O. Paes Leme. Petrópolis,: Vozes, 1990, vol. II, p. 404).

25 Esse tema é recorrente na obra ockhamiana, devido à pretensão papal de possuir o direito de confirmar e mesmo de depor o imperador (Cf., por exemplo, Brev. III, p. 161-193 [93-125]; De imp. et pont., c. 19-23, p. 312-320 [206-214]; Liber VI contra Benedictum, c. 5-19, Opera politica III, p. 277-320 [(trad. portuguesa de J. A. de C. R. de Souza. Livro VI contra Benedito. In: Guilherme de Ockham - Escritos políticos. Porto Alegre/Bragança Paulista: Edipucrs/EUSF, 1999, p. 32-71].

${ }^{26}$ Liber VI contra..., p. 275-276 [30-31] 
bém não possuía plenitude do poder sobre os bens dos fiéis e, menos ainda, sobre os dos infiéis.

Demonstrado que o papa não possuía plenitude de poder sobre os bens materiais, restava, enfim, mostrar qual a autoridade dele sobre os bens espirituais. Quanto a esse tema, convém ter presente que o Venerabilis Inceptor partia de um pressuposto, qual seja o da distinção radical entre a noção de poder temporal e a noção de espiritual. O poder temporal, e nisto estavam concordes os medievais, se caracteriza pela capacidade de coerção: é um poder que pune a quem não o obedece. $^{27}$ Já o poder espiritual não possui força coercitiva alguma. Ele pode admoestar, separar da comunhão, mas nada mais do que isso. Não existem conversões à força: para uma vida virtuosa são levados os aquiescentes, não se constrange ninguém a ela. ${ }^{28}$ Para o lógico Ockham, portanto, era evidente que a palavra "poder' - em se tratando da Igreja - estava sendo usada em sentido equívoco, porque se tratava de um poder que não podia coagir os protervos. Além disso, prosseguindo no trabalho de diferenciação dos poderes, ele considerava o detentor do poder mundano como alguém que devia possuir muitos bens e que aproveitava das benesses do poder - embora o considerasse também como escolhido e legitimado em vista do bem comum -, enquanto o poder eclesiástico era fundamentalmente um ministério, um trabalho a serviço dos fiéis. "O principado papal - dizia ele - foi instituído por causa da utilidade e do proveito dos seus súditos, não por causa da honra ou da glória ou da utilidade ou do proveito temporal do governante, de modo que este principado deve ser justamente chamado de ministrativo e não de dominativo". ${ }^{29}$

Creio que podemos detectar o espírito que o animava, ao tratar dos limites do poder espiritual do papa em um texto, onde é visível a inspiração em Bernardo de Claraval, de quem, aliás, muito se valeu. Dizia ele com uma objetividade nãoisenta de verve:

27 Cf. Dialogus (ed. Goldast, reprint Torino, 1966) III, II, I, c. 1, p. 871; Octo quaest., 3, 8, 1 (Opera politica, vol. I), p. 109 [159]; ibid. 3, 10, I, p. 111 [162].

28 Ockham se vale de duas autoridades para ilustrar o que está dizendo. A de Agostinho (Super Joh., tract. 6, c. 1; PL 22, 533), quando diz que a defesa das propriedades da Igreja se baseia no direito dos imperadores, e não no direito divino, pois que neste nada consta a respeito - o que equivale a dizer que o papa não possui plenitude do poder nas coisas terrenas, mas as deve aos príncipes deste mundo (Brev. II, C. 11, p. 132 [64]. Mais claro ainda é o texto de João Crisóstomo (De sacerdotio II, 3, PG 48, 634): "Os que são juízes fora, quando submetem os maus, demonstram neles muito poder, e retiram-nos constrangidos da pravidade dos antigos costumes; na Igreja, porém, é necessário converter para melhor vida não o coagido, mas o aquiescente, pois que não nos foi conferido pela leis tal poder, de modo que possamos coibir os homens de praticar delitos" ("Hii, qui foris sunt judices, malignos quoque cum subdiderint, ostendunt in eis plurimam potestatem et etiam invitos eos a priorum morum pravitate compescunt. In ecclesia vero non coactum, sed acquiescentem oportet ad meliora converti, quia nec nobis a legibus est data talis potestas ut auctoritate sententiae coibeamus homines a delictis" - Brev. II, c. 11, p. 131 [63-64]).

29 "[...] principatus papalis est propter utilitatem et commodum subditorum institutus et non propter honorem aut gloriam vel utilitatem seu temporale commodum principantis, ita ut principatus non dominativus, sed ministrativus debeat merito appellari" (De imp. et. pont., c. 6, p. 291 [183]); cf. Brev. II, c. 5, p. 116-120 [50-53]. 
Daí, Cristo, ao estabelecer o bem-aventurado Pedro como guia de suas ovelhas, não lhe ter dito: "Tosquia minhas ovelhas e fabrica vestes para ti com sua lã"; nem tampouco lhe falou: "Ordenha as minhas ovelhas e bebe de seu leite", muito menos afirmou: "Mata minhas ovelhas e come de sua carne". Antes lhe ordenou: "Apascenta minhas ovelhas" [Jo 21, 17], quer dizer, "guarda, protege, defende e serve minhas ovelhas, para minha glória e em proveito das mesmas". ${ }^{30}$

O poder concedido por Cristo ao papa é, pois, um poder espiritual e refere-se às suas ovelhas, isto é, aos fiéis - não aos infiéis -. Portanto,

[...] é da competência do papa, e de todos os bispos, em geral, fazer tudo aquilo que é próprio e indispensável aos cristãos, no tocante à leitura da Escritura, à pregação da palavra de Deus, à organização do culto divino, e tudo aquilo que é necessário e próprio dos cristãos, a fim de que possam vir a alcançar a salvação eterna; e tais coisas não há entre os infiéis. ${ }^{31}$

Especificando melhor esta frase, Ockham resume o que tem a dizer a respeito na afirmação de que o poder é limitado pela liberdade - e o poder do papa e de toda a autoridade religiosa é limitado pela liberdade evangélica. Liberdade é uma noção que Ockham traz para o âmago de sua teoria e à qual haverá de recorrer em várias ocasiões. A liberdade, para ele, pertence à constituição do homem, de tal modo que, como diziam seus confrades Pedro Olivi e João Duns Scotus, se o homem fosse dela privado, deixaria de ser homem. O homem preferiria a aniquilação a ser reduzido a uma existência animal, ${ }^{32}$ dizia Olivi, ao que Scotus acrescentava: que o homem, por vezes, deseja a morte ou ser assassinado a viver em escravidão ou em situação semelhante. ${ }^{33}$ Ela constitui, portanto, um direito pré-estatal e pré-

${ }^{30}$ "Hinc Christus praeficiens ovibus suis beatum Petrum non dixit ei: 'Tonde oves meas et fac tibi vestes de lanis earum'; nec dixit: 'Mulge oves meas, et bibe vel comede lac earum'; nec dixit: 'Macta oves meas, et manduca carnes earum'; sed dixit: 'Pasce oves meas", id est: 'serva, rege, custodi et servi eis, ad honorem meum et utilitatem ipsarum' (De imp. et. pont., c. 6, p. 297 [189]); cf. Brev. II, c. 5, p. 116-117 [50]).

${ }^{31}$ "[...] ad papam, sicut generaliter ad omnes episcopos, prout testantur sanctiones canonicae, spectat lectioni, orationi, verbi Dei praedicationi et cultui divino ac omnibus illis, quae sunt necessaria et propria Christianis ad vitam adipiscendam aeternam et apud infideles non existunt, intendere" (De imp. et pont., c. 10, p. 301 [194]).

32 "Unde si cui daretur optio in quod minus vellet redigi, scilicet, in unum animal aut in purum nihil tantum: unusquisque vellet esse nihil, acsi intimo sensu clamet quod omne esse comparatum ad suum est quasi purum nihil" (P. J. Olivi. Quaestiones in II Sententiarum, q. 57, B. Jansen, ed., Quaracchi, 1921-1926, vol. II, p. 334). As questões 57 e 58, já pela sua extensão desproporcionalmente grandes, ocupando somente elas 211 páginas, estão a indicar a importância concedida pelo autor à questão da liberdade humana.

${ }_{33}$ J. Duns Scotus. De perfectione statuum, n. 26. ed. Vivès, vol. XXVI, col. 523b. Diz o texto latino: "[Homo] aliquando propter ... subiectionem et propter talia desiderat mori et occidi ad illorum terminationem". Convém observar que há dúvidas sobre se esta obra pertence a Scotus; mas em outros textos autênticos ele diz algo semelhante, como, por exemplo: "A liberdade é a coisa mais preciosa e mais nobre que existe na alma e, por conseguinte, no homem" (Report. IV, d. 15, q. 4, n. 38; ed. Vivès, vol. XXIV, col. 246a). Do mesmo modo, afirma que nem Deus pode privar o homem da liberdade (Ord. IV, d. 49, q. 6, n. 13-15, ed. Vivès, vol. XXI, col. 232a - 234a) e que a privação da liberdade é uma enorme crueldade porque priva o homem do livre-arbítrio e do domínio de seus atos e o converte em um bruto, que não pode agir virtuosamente (Ibid. d. 36, q. 1, n. 9, vol. XIX, col. 453a). 
eclesial do indivíduo e do cristão e, como tal, não pode ser tangida por leis positivas de nenhuma proveniência. O papa não pode tirar de alguém os direitos que não foi ele a conceder, visto que, como diz o Apóstolo, "a religião cristã não priva a ninguém de seu direito" (Tito 3,1). Por isso, ele "não pode privar as outras pessoas de gozarem das liberdades, as quais lhes foram concedidas por Deus ou pela natureza". ${ }^{34}$ Aqui se encontra o núcleo da oposição de Ockham às pretensões de plenitudo potestatis, por parte do papa e de quem quer que seja. Como tivemos ocasião de dizer alhures, "plenitude do poder e liberdade são conceitos contraditórios, que se excluem mutuamente: a plenitude do poder é algo que destrói tanto o cristão quanto o cidadão, porque rouba-lhes a liberdade". ${ }^{35}$ Onde existe plenitude de poder, a liberdade passa de direito fundamental a simples concessão; o homem passa da situação de livre à de condicionalmente livre ou de escravo. A lei cristã, diz ele, tal como a encontramos em vários tópicos do Novo Testamento, é uma lei de liberdade, que por isso se distingue da lei judaica. Ninguém por ela se torna escravo, por ela não se coloca um jugo pesado sobre as costas de outrem, nem se impõem aos cristãos cerimônias de culto exterior, tão pesadas como eram as do culto judaico. ${ }^{36}$

À luz do que podemos chamar de 'princípio liberdade', explicitam-se, então, os limites dos poderes do sumo pontífice.

O papa não pode impor aos fiéis as práticas judaicas que a lei do Evangelho declarou abolidas, tais como as abluções e a circuncisão. Não pode, igualmente, criar novas práticas semelhantes a essas, porque nem os sumos sacerdotes da Antiga Lei as podiam criar. ${ }^{37}$

Do poder concedido por Cristo a Pedro e seus sucessores, excluem-se, também, por motivo semelhante ao anterior, os modos excessivamente onerosos e difíceis de ordenar, estatuir e fazer naquelas coisas que, por direito conferido por Cristo, estão sujeitas às suas ordens. Esse modo irracional de agir acaba impedindo os fiéis de cumprirem com seu dever e os transforma em escravos do papa, tornando a Nova Lei mais onerosa do que a Antiga. E vindo o papa a agir de tal

${ }_{34}$ "[...] papa non potest aliquos privare iure suo, praesertim quod non habent ab ipso, sed a Deo, vel natura vel alio homine; et eadem ratione non potest aliquos privare libertatibus suis a Deo et a natura eis concessa" (De imp. et.pont., c. 4, p. 287 [179]. Cf. Brev. II, c. 17, p. 146 [77].

${ }^{35}$ L. A. De Boni. De Abelardo a Lutero. Porto Alegre: Edipucrs, 2003, p. 305. Nesse texto, entre as p. 304-309, procuramos mostrar a origem franciscana desse conceito, a importância que ele possui na teoria ockhamiana e o motivo pelo qual se afirma que Ockham é o fundador da teoria dos direitos subjetivos.

36 "[...] per legem evangelicam nullatenus iugum grave inducitur et nullus per ipsam fit servus alterius, nec tantum onus quoad exteriorem cultum divinum per ipsam imponitur Christianis quanto Iudaei pressi fuerunt" (Brev. II, c. 4, p. 116 [49]).

37 "Sicut enim summus sacerdos veteris legis ultra caerimonialia, sacramentalia et iudiciaria, quae in eadem lege erant expressa, non poterat novas traditiones, praecipue populo notabiliter onerosas, inducere aut statuere: sic nec sacerdos summus in evangelica lege potest aliquas novitates, potisime onerosas et graves, catholicis, sine culpa sibi subiectorum et absque necessitate urgenti vel manifesta utilitate, ultra illa, quae expressa sunt in Novo Testamento, inducere, ut non maioris servitutis sit lex nova quam vetus" (Brev. II, c. 17, p. 146 [77]). 
maneira, deve ser considerado como juiz não-competente para proferir tal sentença e, por isso, o atingido não está obrigado a obedecer. ${ }^{38}$

Não lhe cabe também impor, contra a vontade do indivíduo, a prática daquelas obras conhecidas como supererogação, isto é, aquelas ações virtuosas que o Evangelho ou a vida cristã recomendam, mas não impõem aos fiéis. Assim, por exemplo, em diversos tópicos da Escritura, a virgindade e o celibato são louvados; contudo, não pertencem à mediania dos fiéis, mas levam em si algo que vai além das obrigações comuns a todos. Por isso, eles não são impostos a ninguém, mas apenas aconselhados aos que aspiram a uma maior perfeição. De modo semelhante, após anos de convivência, marido e mulher podem, de comum acordo, decidirse pela separação, a fim de seguirem, ambos, como freira e frade, digamos, a vida celibatária. Mas o papa não pode impor aos cônjuges, contra a vontade deles, que, para salvação de suas almas, deixem de coabitar e se tornem religiosos. ${ }^{39}$

Enfim, estão excluídas do poder do papa as coisas frívolas, inúteis e indiferentes, embora, algumas vezes, por reverência, a gente o deva obedecer em tais circunstâncias. Assim, se o papa dissesse a alguém que lhe trouxesse um copo dágua, ou que levasse uma cadeira para outro lugar, o solicitado deveria levar em conta a dignidade do cargo pontifício e fazer a obra solicitada, que não seria nem desonesta, nem onerosa. ${ }^{40}$

\section{Concluindo}

É provável que, para nós, a concepção de Igreja de Guilherme de Ockham acabe obnubilada pelos mais de seis séculos que se interpõem entre ele e nós. E por isso, talvez, não percebamos todo seu alcance histórico.

Esse frade franciscano, com a experiência de pobreza absoluta - em defesa da qual a Ordem se rebelara contra o papado de Avinhão -, concebia a Igreja como uma grande fraternidade, fraternal - não imperialmente - dirigida pelo papa. Como poucos ele compreendeu que, sem pompas, sem posses, sem super-poderes, a Igreja se tornava o contraponto e o corretivo dos poderes mundanos.

A plenitude do poder, percebia ele, transformava o papa em imperador, em sucessor de Augusto, não de Cristo; de Carlos Magno, não de Pedro, e com isso, como já observara são Bernardo, o sumo pontífice abandonava o cajado de pastor para empunhar o cetro real.

\footnotetext{
${ }^{38}$ "A potestate igitur promissa Petro et succesoribus eius [...] excipi debet modus irrationabiliter gravis et onerosus subiectis [...] Quia nec de iure potest, quod leve est, redere eis difficile, ne redigat in servitutem fideles contra libertatem evangelicae legis [...] Posset enim ita modum in illis, quae de iure potest, excedere quod multo tolerabilior fuisset conditio Iudaeorum quam esset conditio Christianorum" (Brev. II, 18, p. 149-150 [81-83]). Cf. De imp. et pont., c. 5, p. 290 [182].

${ }_{39}$ "Si enim papa in huiusmodi haberet potestatem condendi leges obligatorias, Christianis invitis, posset quaemcumque Christianum cogere invitum intrare in religionem quamcumque, et cui velet ieiunium continuum in pane et acqua, saltem necessitatem extremam, iniungere, et quilibet pro suae arbitrio voluntatis abdicationis proprietatis omnium rerum indicere" (Brev. II, c. 17, p. 148 [7879]. Cf. De imp. et pont., c. 3, p. 286-287 [177-178]).

${ }^{40}$ Cf. De imp. et pont. c. 5, p. 289-290 [181].
} 
A seu modo, o Venerabilis Inceptor repetia o que o papa Gelásio dizia em sua clássica epístola ao imperador Anastácio: que o papa não possui poder, possui autoridade - auctoritas - aquele poder moral que dispensa a força das armas. E lá estava o exemplo de Francisco de Assis, pobre e contemplante, mas que modificara no âmago a Cristandade, a ponto de, quase oitocentos anos depois, os laicizados homens do final do século XX o terem eleito como a personalidade do milênio.

Era possível tal Igreja no turbilhão do século XIV? Talvez não, talvez fosse apenas uma utopia. Mas as utopias colocam a história em movimento e um dia se tornam realidade. E um dia a Igreja foi violentamente privada de seus domínios temporais e o papa se declarou prisioneiro do Vaticano. O baque não lhe permitiu perceber que, em verdade, ele estava se tornando livre, estava ganhando em autoridade o que havia perdido em poder. Morria a Igreja do papa-césar Bonifácio VIII, do papa-financista João XXII, e do papa-general Júlio II, e só assim pôde dela nascer a Igreja de João XXIII e João Paulo II. 